\title{
Effect of Integrated Phosphorus Management on Growth and Yield of Groundnut (Arachis hypogaea L.)
}

\author{
Rajbala Sharma*, S. S. Yadav, Jitendra Singh Bamboriya and Sarita \\ ${ }^{1}$ Department of Agronomy, S.K.N. College of Agriculture, Jobner, Jaipur (Rajasthan), India \\ ${ }^{2}$ Department of Agronomy, College of Agriculture, \\ Mandor, AU, Jodhpur (Rajasthan), 342304, India \\ ${ }^{3}$ Department of Soil science, Maharana Pratap University of Agriculture \\ and Technology, Udaipur, India \\ *Corresponding author
}

\begin{tabular}{|l|}
\hline K e y w o r d s \\
Phosphorus, PSB, \\
Growth, Yield, \\
Groundnut \\
\hline Article Info \\
\hline $\begin{array}{l}\text { Accepted: } \\
10 \text { March } 2020 \\
\text { Available Online: } \\
10 \text { April } 2020\end{array}$ \\
\hline
\end{tabular}

\section{A B S T R A C T}

A field experiment was conducted at Agronomy farm, S.K.N. College of Agriculture, Jobner (Rajasthan) during kharif season of 2017 on loamy sand soil. The experiment was laid down in randomized block design with eleven phosphorus management treatments (Control, 100\% RDF, 75\% P through inorganic + 25\% through FYM, 75\% P through inorganic $+25 \%$ through $\mathrm{VC}, 75 \% \mathrm{P}$ through inorganic $+25 \%$ through $\mathrm{PM}, 50 \% \mathrm{P}$ through inorganic $+50 \%$ through FYM, 50\% P through inorganic $+50 \%$ through VC, $50 \% \mathrm{P}$ through inorganic $+50 \%$ through $\mathrm{PM}, 25 \% \mathrm{P}$ through inorganic $+75 \%$ through FYM, 25\% P through inorganic $+75 \%$ through VC, 25\% P through inorganic $+75 \%$ through PM) and two treatments of microbial inoculation (uninoculated and seed inoculation with PSB). Results revealed that among phosphorus management treatments, application of 50\% $\mathrm{P}$ through inorganic $+50 \%$ through $\mathrm{VC}$ significantly increased the growth characters and yield of groundnut viz., crop dry matter accumulation at most of the stages, number and weight of root nodules/plant, CGR and chlorophyll content over rest of the treatments. It also recorded the significantly highest pod yield $(2198 \mathrm{~kg} / \mathrm{ha})$, haulm yield (3009 kg/ha) and biological yield (5207 kg/ha) of groundnut. However, it showed statistical equivalence with 50\% P through inorganic $+50 \%$ through PM in most of the growth and yield of the crop. Results further indicated that inoculation of groundnut seed with PSB significantly enhanced the growth characters and yield over uninoculated control. Seed inoculation with PSB also improved to pod, haulm and biological yield of groundnut to the extent of 20.3, 12.4 and 15.7 per cent over control, respectively.

\section{Introduction}

Groundnut (Arachis hypogaea L.) is a selfpollinated, annual, herbaceous, autotetrapliod legume with $2 \mathrm{n}=40$ chromosomes belonging to the family leguminoseae (Fabaceae). It is known by various names as "wondernut", "Poor man's Cashewnut", "Peanut" "Monkey nut", "Earth nut" or "King of Oilseeds". It is the thirteenth most important food crop of the 
world; fourth most important source of edible oil and the third most important source of vegetable protein (Sorrensen et al., 2004; Taru et al., 2008). This crop has own importance due to high edible oil content and nutritional value of kernel as human food, and haulm as rich feed for animals. Peanut is very important source of oil (40$45 \%)$, protein $(26 \%)$, carbohydrates $(25 \%)$, minerals (Phosphorus, calcium and iron) and vitamins (vitamin B complex like thiamine, riboflavin, niacin and vitamin $\mathrm{E}$ ) in addition to higher proportion of unsaturated fatty acids, including essential fatty acids like linolenic and linoleic acids.

Nutrient management is one of the crucial factors deciding productivity of the crop. Phosphorus is an essential element in crop production. It plays an important role in root development, crop maturation, photosynthesis, nodulation, $\mathrm{N}_{2}$-fixation and other vital processes. It is a key constituent of ATP and plays a significant role in transformation of energy in plants, as well as various roles in seed formation. Phosphorus application increases groundnut yield and its yield contributing characters (Hasan and Ismail, 2016). Most of soils of Rajasthan are poor in available phosphorus supply and low in organic matter.

Phosphate solubilizing bacteria (PSB) are a group of beneficial bacteria capable of hydrolysing organic and inorganic phosphorus from insoluble compounds. Psolubilization ability of the microorganisms is considered to be one of the most important traits associated with plant phosphate nutrition. The inoculation of PSB secretes phosphate solubilizer that helps in conversion of unavailable to available form of phosphorus which increases yield of crops by $10-30 \%$ (Tilak and Annapurna, 1993). Keeping this in view the field experiment was conducted to study the effect of integrated phosphorus management on growth and yield of groundnut.

\section{Materials and Methods}

The field experiment was conducted during kharif season of 2017 on loamy sand soil at Agronomy farm, S.K.N. College of Agriculture, Jobner (Rajasthan). The soil of experimental plot was alkaline in reaction (PH-8.2), poor in organic carbon $(0.24 \%)$, low in available nitrogen $\left(125.7 \mathrm{~kg} \mathrm{ha}^{-1}\right)$ and phosphorus (7.04 $\mathrm{kg} \mathrm{ha}^{-1}$ ) and potassium $\left(125.52 \mathrm{~kg} \mathrm{ha}^{-1}\right)$. The treatment were laid down in randomized block design and replicated thrice.

The experiment consisted eleven treatments of phosphorus management through organic and inorganic sources (Control, 100\% RDF, $75 \% \mathrm{P}$ through inorganic $+25 \%$ through FYM, $75 \% \mathrm{P}$ through inorganic $+25 \%$ through $\mathrm{VC}, 75 \% \mathrm{P}$ through inorganic $+25 \%$ through PM, 50\% P through inorganic $+50 \%$ through FYM, 50\% $\mathrm{P}$ through inorganic + $50 \%$ through VC, 50\% P through inorganic + $50 \%$ through PM, 25\% P through inorganic + $75 \%$ through FYM, 25\% P through inorganic $+75 \%$ through $\mathrm{VC}, 25 \% \mathrm{P}$ through inorganic $+75 \%$ through PM) and two treatments of microbial inoculation (PSB) (uninoculated and seed inoculation with PSB) thereby making twenty two treatment combinations.

Groundnut RG-425 was sown directly using seed rate of $100 \mathrm{Kg} \mathrm{ha-}{ }^{1}$ in $4.0 \mathrm{~m} \mathrm{x} 3.15 \mathrm{~m}$ size plots with plant geometry of $45 \mathrm{~cm} \times 10$ $\mathrm{cm}$. Nitrogen and phosphorus were applied through Urea and SSP as per treatments taking $20 \mathrm{~kg} / \mathrm{ha} \mathrm{N}$ and $40 \mathrm{~kg} \mathrm{P}_{2} \mathrm{O}_{5} / \mathrm{ha}$ as $100 \%$ fertility levels. Whole amount of nitrogen and phosphorus was drilled $8-10 \mathrm{~cm}$ deep in soil at the time of sowing as per treatments. FYM, vermicompost and poultry manure were applied prior to cross ploughing and 
incorporated thoroughly in soil with the help of cultivator as per treatments. The nutrient composition of FYM, vermicompost and poultry manure was $0.48 ; 1.22$ and 3.5 per cent $\mathrm{N} ; 0.23 ; 0.70$ and 2.5 per cent $\mathrm{P}$ and $0.42 ; 1.03$ and 1.8 per cent $\mathrm{K}$, respectively. The amount of these manures was calculated on the basis of their P content. Groundnut seed were inoculated with PSB cultures as per treatment by using three packets ( $200 \mathrm{~g}$ each) for $100 \mathrm{~kg}$ seed of groundnut needed for sowing one hectare area.

First of all, about $0.5 \mathrm{~kg}$ jaggery was mixed in 2 liters of water and boiled. After cooling it, PSB cultures were mixed in the solution as treatments and stirred well for proper mixing. The seeds were spread on a jute mat, sprinkled with culture solution and mixed with hands for proper coating. After drying in shade, the seeds were used for sowing. A uniform dose of $40 \mathrm{Kg}$ sulphur per hectare was applied through SSP to all the treatments. Need based cultural and plant protection operations were taken up to harvest good crop.

Dry matter accumulation was also recorded at 35,70 DAS and at harvest stages by removing plants from one meter row length from the outer sample rows in each plot. The root portion was removed and the samples were first dried in air and then in an electric oven at $70{ }^{\circ} \mathrm{C}$ till constant weight. Plant stand and dry matter accumulation were recorded by removing plants from one meter row length from the outer sample rows in each plot.

Five random plants were selected from each plot for taking observations on number and weight (fresh and dry) of nodules/plant. The CGR and mean relative growth rate (RGR) of the crop was calculated by the following formula (Radford, 1967). The chlorophyll content at 45 DAS was estimated using method advocated by Arnon (1949). The experimental data recorded for Plant growth, yield and other characters were statistically analysed by Fisher's 'Analysis of Variance' technique (Fisher, 1950). Critical difference (CD) was worked out wherever the difference was found significant at 5.0 or 1.0 per cent level of significance.

\section{Results and Discussion}

\section{Effect of phosphorous management}

Phosphorous management significantly influenced the plant growth viz., dry matter accumulation, Crop growth rate, total number of nodules/plant, number of effective nodules/plant, fresh weight of nodules/plant dry weight of nodules/plant and chlorophyll content except for plant stand and mean relative growth rate.

Among different Phosphorus management used under present investigation, application of $50 \% \mathrm{P}$ through inorganic $+50 \%$ through VC was recorded maximum dry matter accumulation of 22.48 (35 DAS), 232.25 (70 DAS) and 473.07 (At harvest) $\mathrm{g} / \mathrm{m}$ row length which was significantly superior over rest of the treatments except $50 \%$ P through inorganic $+50 \%$ through $\mathrm{PM}$ and also attained CGR values of $1.43,13.32$ and 9.73 $\mathrm{g} / \mathrm{m}^{2} /$ day during 0-35 DAS, 35-70 DAS and 70 DAS-harvest stages, respectively that were 34.9 and 48.9 per cent higher during 0-35 DAS; 22.4 and 38.4 per cent during 35-70 DAS and 32.7 and 45.8 per cent during 70 DAS-harvest stage over $25 \% \quad \mathrm{P}$ through inorganic $+75 \%$ through FYM and control, respectively.

Application of $50 \% \mathrm{P}$ through inorganic + $50 \%$ through poultry manure also increased the CGR values by $39.6,39.2$ and 33.7 per cent over control during these stages. Application of $50 \% \mathrm{P}$ through inorganic + $50 \%$ through vermicompost significantly 
increased the total number of nodules/plant (67.0) and number of effective nodules/plant (60.4) over rest of the treatments except $50 \%$ $\mathrm{P}$ through inorganic $+50 \%$ through PM, 75\% $\mathrm{P}$ through inorganic $+25 \%$ through $\mathrm{VC}$ and $75 \% \mathrm{P}$ through inorganic $+25 \%$ through $\mathrm{PM}$. These four treatments increased the total nodules/plant by 48.6, 45.9, 45.2 and 45.2 per cent over control, respectively. The highest fresh weight $(238 \mathrm{mg})$, dry weight of nodules/plant $(106.0 \mathrm{mg})$ and chlorophyll content $(3.84 \mathrm{mg} / \mathrm{g})$ were recorded under $50 \%$ $\mathrm{P}$ through inorganic $+50 \%$ through $\mathrm{VC}$ treatment. Application of $50 \% \mathrm{P}$ through inorganic $+50 \%$ through VC produced the significantly highest pod, haulm, biological and kernel yields of groundnut (2198, 3009, 5207 and $1560 \mathrm{~kg} / \mathrm{ha}$ ). However, it showed statistical equivalence with $50 \% \mathrm{P}$ through inorganic $+50 \%$ through PM.

Addition of phosphatic fertilizers and combined application of NPK to the groundnut increased the availability of major nutrients to plant as it might has enhanced early root growth and cell multiplication leading to more absorption of other nutrients from deeper layers of soil ultimately resulting in increased plant growth in terms of crop dry matter accumulation and CGR. These results are in close conformity with the findings Murthy et al., (2009), Dhadge and Satpute (2014), Das et al., (2015) and Choudhary et al., (2017b) in groundnut (Fig. 1 and Table 1).

\section{Effect of microbial inoculation}

The data revealed that seed inoculation with PSB recorded significantly higher crop dry matter, CGR, number and weight of nodules and chlorophyll content than uninoculated control (Table 2 and 3). The highest dry matter, CGR number, fresh weight of nodules (233.7 $\mathrm{mg} / \mathrm{plant})$ and dry weight of nodules (102.9 mg/plant) and chlorophyll content (3.56 mg/g) were obtained when groundnut seed was inoculated with PSB. The per cent increase in dry matter incurred due to this treatment was $11.9,13.0$ and 11.8 per cent at 35 DAS, 70 DAS and at harvest over uninoculated control, respectively. The highest CGR values during 0-35 DAS; 35-70 DAS and 70 DAS- harvest stages were obtained when groundnut seed was inoculated with PSB (1.29, 13.03 and $8.61 \mathrm{~g} / \mathrm{m}^{2} /$ day $)$.

It thus increased the CGR to the extent of 12.1, 13.1 and 10.6 per cent over control at these three stages, respectively. Seed inoculation with PSB recorded the highest number of 64.6 nodules/plant and 57.4 effective nodules/plant that were 18.9 and 19.1 per cent, respectively more than noted under control. The highest pod, haulm, biological and kernel yields (2000, 2659, 4659 and $1420 \mathrm{~kg} / \mathrm{ha}$ ) were obtained under the treatment PSB. Seed inoculation with PSB increased the pod, haulm, biological and kernel yields to the extent of 20.3, 12.4,15.7 and 20.3 per cent, respectively over control. Seed inoculation with PSB recorded significantly higher crop dry matter, CGR number and weight of nodules and chlorophyll content over no inoculation. It is obvious because of the fact that PSB produces organic acids like gluconic, succinic, lactic, oxalic, citric and $\alpha$-ketogluconic acids in micro environment around the roots (Table 4).

The role of these organic acids in solublizing mineral phosphates and phosphorylated minerals is attributed to the lowering $\mathrm{pH}$ which helps in release of phosphorus from the stable complexes with cations such as $\mathrm{Ca}^{++}$, $\mathrm{Mg}^{++}$which results in effective solublization of phosphates and also synthesizes growth promoting substances which augment plant growth. The results obtained in present investigation are in line with the findings of Zalate and Padmani (2009) and Patil et al., (2014) in groundnut who recorded improvement in growth parameters and nodulation due to seed inoculation with PSB. 
Table.1 Effect of integrated phosphorus management on plant stand and crop dry matter accumulation in groundnut

\begin{tabular}{|c|c|c|c|c|c|}
\hline \multirow[t]{2}{*}{ Treatments } & \multicolumn{2}{|c|}{ Plant stand/m } & \multicolumn{3}{|c|}{ Dry matter (g/m row length) } \\
\hline & 20 & At & 35 & 70 & At \\
\hline \multicolumn{6}{|l|}{ Phosphorus management } \\
\hline$P_{0^{-}}$control & 10.09 & 9.31 & 15.06 & 166.66 & 331.70 \\
\hline$P_{1-} 100 \%$ RDF & 10.28 & 9.50 & 18.87 & 211.14 & 409.31 \\
\hline $\begin{array}{l}P_{2-} 75 \% \text { P through inorganic }+25 \% \\
\text { through FYM }\end{array}$ & 10.26 & 9.48 & 19.06 & 211.39 & 409.84 \\
\hline $\begin{array}{l}P_{3-}-75 \% P \text { through inorganic }+25 \% \\
\text { through vermicompost }\end{array}$ & 9.89 & 9.11 & 21.25 & 231.84 & 449.16 \\
\hline $\begin{array}{l}P_{4-}-75 \% P \text { through inorganic }+25 \% \\
\text { through poultry manure }\end{array}$ & 9.94 & 9.16 & 21.04 & 231.80 & 447.09 \\
\hline $\begin{array}{l}P_{5}-50 \% \text { P through inorganic }+50 \% \\
\text { through FYM }\end{array}$ & 10.45 & 9.67 & 19.39 & 211.49 & 410.01 \\
\hline $\begin{array}{l}P_{6-} 50 \% P \text { through inorganic }+50 \% \\
\text { through vermicompost }\end{array}$ & 9.95 & 9.17 & 22.48 & 232.25 & 473.07 \\
\hline $\begin{array}{l}P_{7-50 \%} P \text { through inorganic }+50 \% \\
\text { through poultry manure }\end{array}$ & 9.83 & 9.05 & 21.12 & 232.06 & 452.76 \\
\hline $\begin{array}{l}P_{8}-25 \% \text { P through inorganic }+75 \% \\
\text { through FYM }\end{array}$ & 10.11 & 9.33 & 16.67 & 188.08 & 369.58 \\
\hline $\begin{array}{l}P_{9-} 25 \% \text { P through inorganic }+75 \% \\
\text { through vermicompost }\end{array}$ & 10.17 & 9.39 & 18.50 & 210.82 & 408.65 \\
\hline $\begin{array}{l}P_{10^{-}} 25 \% \mathrm{P} \text { through inorganic }+75 \% \\
\text { through poultry manure }\end{array}$ & 10.06 & 9.28 & 18.26 & 210.41 & 408.04 \\
\hline SEm \pm & 0.38 & 0.31 & 0.55 & 7.02 & 12.71 \\
\hline $\mathrm{CD}(\mathrm{P}=\mathbf{0 . 0 5})$ & NS & NS & 1.58 & 20.02 & 36.27 \\
\hline \multicolumn{6}{|l|}{ Microbial inoculation } \\
\hline $\mathbf{I}_{0}$ - Uninoculated & 10.18 & 9.40 & 18.16 & 199.54 & 392.15 \\
\hline$I_{1}$ - Seed inoculation with PSB & 10.01 & 9.23 & 20.33 & 225.54 & 438.61 \\
\hline $\mathrm{SEm} \pm$ & 0.16 & 0.13 & 0.24 & 2.99 & 5.42 \\
\hline $\mathrm{CD}(\mathrm{P}=\mathbf{0 . 0 5})$ & NS & NS & 0.67 & 8.54 & 15.46 \\
\hline CV $(\%)$ & 9.13 & 8.15 & 7.05 & 8.09 & 7.49 \\
\hline
\end{tabular}


Table.2 Effect of integrated phosphorus management on mean crop growth rate (CGR) and RGR (mg/g/day) in groundnut

\begin{tabular}{|c|c|c|c|c|c|}
\hline \multirow[t]{2}{*}{ Treatments } & \multicolumn{3}{|c|}{ CGR $\left(\mathrm{g} / \mathrm{m}^{2} /\right.$ day $)$} & \multicolumn{2}{|c|}{ RGR (mg/g/day) } \\
\hline & $\begin{array}{l}\text { 0 - 35 } \\
\text { DAS }\end{array}$ & $\begin{array}{c}35-70 \\
\text { DAS }\end{array}$ & $\begin{array}{l}\text { 70 DAS - } \\
\text { harvest }\end{array}$ & $\begin{array}{l}35-70 \\
\text { DAS }\end{array}$ & $\begin{array}{l}70 \text { DAS - } \\
\text { harvest }\end{array}$ \\
\hline \multicolumn{6}{|l|}{ Phosphorus management } \\
\hline $\mathbf{P}_{0^{-}}$control & 0.96 & 9.62 & 6.67 & 68.67 & 12.52 \\
\hline$P_{1}-100 \%$ RDF & 1.20 & 12.21 & 8.01 & 68.99 & 12.04 \\
\hline $\begin{array}{l}P_{2}-75 \% \text { P through inorganic }+25 \% \\
\text { through FYM }\end{array}$ & 1.21 & 12.21 & 8.02 & 68.74 & 12.04 \\
\hline $\begin{array}{l}P_{3}-75 \% P \text { through inorganic }+25 \% \\
\text { through vermicompost }\end{array}$ & 1.35 & 13.37 & 8.78 & 68.27 & 12.03 \\
\hline $\begin{array}{l}P_{4-}-75 \% P \text { through inorganic }+25 \% \\
\text { through poultry manure }\end{array}$ & 1.34 & 13.38 & 8.70 & 68.55 & 11.95 \\
\hline $\begin{array}{l}P_{5}-50 \% \text { P through inorganic }+50 \% \\
\text { through FYM }\end{array}$ & 1.23 & 12.20 & 8.02 & 68.26 & 12.04 \\
\hline $\begin{array}{l}P_{6}-50 \% P \text { through inorganic }+50 \% \\
\text { through vermicompost }\end{array}$ & 1.43 & 13.32 & 9.73 & 66.72 & 12.94 \\
\hline $\begin{array}{l}P_{7}-50 \% P \text { through inorganic }+50 \% \\
\text { through poultry manure }\end{array}$ & 1.34 & 13.39 & 8.92 & 68.47 & 12.16 \\
\hline $\begin{array}{l}P_{8-}-25 \% \text { P through inorganic }+75 \% \\
\text { through FYM }\end{array}$ & 1.06 & 10.88 & 7.33 & 69.23 & 12.29 \\
\hline $\begin{array}{l}P_{9}-25 \% P \text { through inorganic }+75 \% \\
\text { through vermicompost }\end{array}$ & 1.17 & 12.21 & 7.99 & 69.51 & 12.04 \\
\hline $\begin{array}{l}P_{10}-25 \% P \text { through inorganic }+75 \% \\
\text { through poultry manure }\end{array}$ & 1.16 & 12.20 & 7.98 & 69.83 & 12.05 \\
\hline SEm \pm & 0.03 & 0.35 & 0.23 & 2.64 & 0.34 \\
\hline $\mathrm{CD}(\mathbf{P}=\mathbf{0 . 0 5})$ & 0.09 & 1.01 & 0.65 & NS & NS \\
\hline \multicolumn{6}{|l|}{ Microbial inoculation } \\
\hline $\mathbf{I}_{0}$ - Uninoculated & 1.15 & 11.52 & 7.78 & 68.52 & 12.29 \\
\hline$I_{1}$ - Seed inoculation with PSB & 1.29 & 13.03 & 8.61 & 68.80 & 12.09 \\
\hline SEm \pm & 0.01 & 0.15 & 0.10 & 1.13 & 0.14 \\
\hline $\mathrm{CD}(\mathrm{P}=\mathbf{0 . 0 5})$ & 0.04 & 0.43 & 0.28 & NS & NS \\
\hline CV $(\%)$ & 6.59 & 7.05 & 6.77 & 9.43 & 6.75 \\
\hline
\end{tabular}


Table.3 Effect of integrated phosphorus management on number and weight of nodules/plant and chlorophyll content in groundnut

\begin{tabular}{|c|c|c|c|c|c|}
\hline \multirow[t]{2}{*}{ Treatments } & \multicolumn{2}{|c|}{$\begin{array}{c}\text { Number of } \\
\text { nodules/plant }\end{array}$} & \multicolumn{2}{|c|}{$\begin{array}{c}\begin{array}{c}\text { Weight of } \\
\text { nodules/plant } \\
\text { (mg) }\end{array} \\
\end{array}$} & \multirow[t]{2}{*}{$\begin{array}{l}\text { Chlorophyll } \\
\text { content } \\
\text { ( } \mathrm{mg} / \mathrm{g} \text { of } \\
\text { fresh weight) }\end{array}$} \\
\hline & Total & Effective & Fresh & Dry & \\
\hline \multicolumn{6}{|l|}{ Phosphorus management } \\
\hline $\mathbf{P}_{0^{-}}$control & 45.1 & 40.4 & 171.0 & 74.3 & 2.76 \\
\hline 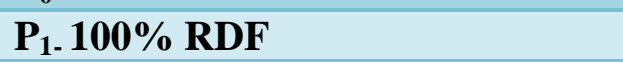 & 58.4 & 51.5 & 215.4 & 92.8 & 3.37 \\
\hline $\begin{array}{l}P_{2}-75 \% \text { P through inorganic }+ \\
25 \% \text { through FYM }\end{array}$ & 58.6 & 52.4 & 218.8 & 94.5 & 3.38 \\
\hline $\begin{array}{c}P_{3-}-75 \% \text { P through inorganic }+ \\
25 \% \text { through vermicompost }\end{array}$ & 65.5 & 59.6 & 230.7 & 102.5 & 3.80 \\
\hline $\begin{array}{l}P_{4}-75 \% \mathrm{P} \text { through inorganic }+ \\
25 \% \text { through poultry manure }\end{array}$ & 65.5 & 58.5 & 229.3 & 98.9 & 3.75 \\
\hline $\begin{array}{l}P_{5}-50 \% \text { P through inorganic }+ \\
50 \% \text { through FYM }\end{array}$ & 58.9 & 50.5 & 223.1 & 95.1 & 3.43 \\
\hline $\begin{array}{l}P_{6}-50 \% \text { P through inorganic }+ \\
50 \% \text { through vermicompost }\end{array}$ & 67.0 & 60.4 & 238.0 & 106.0 & 3.84 \\
\hline $\begin{array}{r}P_{7^{-}} \mathbf{5 0 \%} \mathrm{P} \text { through inorganic }+ \\
\mathbf{5 0 \%} \text { through poultry manure }\end{array}$ & 65.8 & 57.6 & 234.6 & 104.2 & 3.82 \\
\hline $\begin{array}{l}P_{8}-25 \% \text { P through inorganic }+ \\
75 \% \text { through FYM }\end{array}$ & 52.5 & 45.8 & 193.1 & 83.5 & 3.05 \\
\hline $\begin{array}{r}P_{9-}-25 \% \text { P through inorganic }+ \\
75 \% \text { through vermicompost }\end{array}$ & 58.2 & 51.7 & 214.0 & 91.3 & 3.35 \\
\hline $\begin{array}{l}P_{10^{-}} \mathbf{2 5 \%} P \text { through inorganic }+ \\
75 \% \text { through poultry manure }\end{array}$ & 58.2 & 52.5 & 211.6 & 88.0 & 3.33 \\
\hline $\mathrm{SEm} \pm$ & 1.9 & 1.5 & 6.3 & 2.7 & 0.10 \\
\hline CD $(P=0.05)$ & 5.3 & 4.4 & 18.0 & 7.7 & 0.28 \\
\hline \multicolumn{6}{|l|}{ Microbial inoculation } \\
\hline I ${ }_{0}$ - Uninoculated & 54.3 & 48.2 & 198.9 & 84.6 & 3.33 \\
\hline $\mathbf{I}_{1}$ - Seed inoculation with PSB & 64.6 & 57.4 & 233.7 & 102.9 & 3.56 \\
\hline SEm \pm & 0.8 & 0.7 & 2.7 & 1.1 & 0.04 \\
\hline $\mathrm{CD}(\mathrm{P}=0.05)$ & 2.3 & 1.9 & 7.7 & 3.3 & 0.12 \\
\hline $\mathrm{CV}(\%)$ & 7.74 & 7.1 & 7.26 & 7.01 & 7.08 \\
\hline
\end{tabular}


Table.4 Effect of integrated phosphorus management on pod, haulm, biological and kernel yields in groundnut

\begin{tabular}{|c|c|c|c|c|c|}
\hline \multirow[t]{2}{*}{ Treatments } & & \multicolumn{4}{|c|}{ Yield (kg/ha) } \\
\hline & & Pod & Haulm & Biological & Kernel \\
\hline \multicolumn{6}{|l|}{ Phosphorus management } \\
\hline $\mathbf{P}_{0^{-}}$control & & 1222 & 1735 & 2957 & 868 \\
\hline$P_{1}-100 \%$ RDF & & 1859 & 2554 & 4413 & 1320 \\
\hline $\begin{array}{l}P_{2}-75 \% P \text { through inorganic } \\
25 \% \text { through FYM }\end{array}$ & + & 1869 & 2561 & 4430 & 1327 \\
\hline $\begin{array}{c}P_{3^{-}} 75 \% P \text { through inorganic } \\
\text { through vermicompost }\end{array}$ & $+25 \%$ & 2036 & 2799 & 4835 & 1446 \\
\hline $\begin{array}{l}P_{4}-75 \% P \text { through inorganic } \\
25 \% \text { through poultry manure }\end{array}$ & + & 2029 & 2791 & 4820 & 1441 \\
\hline $\begin{array}{l}P_{5}-50 \% \text { P through inorganic } \\
\text { through FYM }\end{array}$ & $+50 \%$ & 1876 & 2571 & 4447 & 1332 \\
\hline $\begin{array}{l}P_{6}-50 \% P \text { through inorganic } \\
50 \% \text { through vermicompost }\end{array}$ & + & 2198 & 3009 & 5207 & 1560 \\
\hline $\begin{array}{l}P_{7-} 50 \% \mathrm{P} \text { through inorganic } \\
\text { through poultry manure }\end{array}$ & $+\mathbf{5 0 \%}$ & 2075 & 2835 & 4910 & 1473 \\
\hline $\begin{array}{l}P_{8}-25 \% \text { P through inorganic } \\
75 \% \text { through FYM }\end{array}$ & + & 1555 & 2102 & 3657 & 1104 \\
\hline $\begin{array}{l}P_{9-} 25 \% P \text { through inorganic } \\
\text { through vermicompost }\end{array}$ & $+75 \%$ & 1715 & 2339 & 4054 & 1218 \\
\hline $\begin{array}{l}P_{10-} 25 \% P \text { through inorganic } \\
\text { through poultry manure }\end{array}$ & $+75 \%$ & 1708 & 2334 & 4042 & 1213 \\
\hline SEm \pm & & 53 & 76 & 147 & 53 \\
\hline $\mathrm{CD}(\mathrm{P}=\mathbf{0 . 0 5})$ & & 152 & 217 & 419 & 151 \\
\hline \multicolumn{6}{|l|}{ Microbial inoculation } \\
\hline $\mathbf{I}_{0}$ - Uninoculated & & 1662 & 2365 & 4027 & 1180 \\
\hline $\mathbf{I}_{1}$ - Seed inoculation with PSB & & 2000 & 2659 & 4659 & 1420 \\
\hline SEm \pm & & 23 & 32 & 63 & 23 \\
\hline $\mathrm{CD}(\mathrm{P}=\mathbf{0 . 0 5})$ & & 65 & 92 & 179 & 64 \\
\hline CV $(\%)$ & & 7.14 & 7.41 & 8.28 & 9.97 \\
\hline
\end{tabular}


Table.5 Correlation coefficients and linear regression equations showing relationship between pod yield ( $\mathrm{kg} / \mathrm{ha})$ and independent variables $(\mathrm{X})$

\begin{tabular}{|c|l|c|c|}
\hline S. No. & Independent variables $(\mathbf{X})$ & $\begin{array}{c}\text { Correlation } \\
\text { coefficients }(\mathbf{r})\end{array}$ & $\begin{array}{c}\text { Regression equations } \\
\left(\mathbf{Y}=\mathbf{a}+\mathbf{b}_{\mathbf{y x}} \mathbf{X}\right)\end{array}$ \\
\hline $\mathbf{1 .}$ & Crop dry matter at harvest $(\mathrm{kg} / \mathrm{ha})$ & $0.981^{* *}$ & $\mathrm{Y}=-1016.199+6.854 \mathrm{X}_{1}$ \\
\hline $\mathbf{2 .}$ & Total number of nodules per plant & $0.972 * *$ & $\mathrm{Y}=-407.622+37.669 \mathrm{X}_{5}$ \\
\hline $\mathbf{3 .}$ & Effective number of nodules per plant & $0.986^{* *}$ & $\mathrm{Y}=-376.932+39.214 \mathrm{X}_{6}$ \\
\hline $\mathbf{4 .}$ & Fresh weight of nodules $(\mathrm{mg})$ & $0.956^{* *}$ & $\mathrm{Y}=-747.904+11.922 \mathrm{X}_{7}$ \\
\hline $\mathbf{5 .}$ & Dry weight of nodules $(\mathrm{mg})$ & $0.959 * *$ & $\mathrm{Y}=-377.025+23.557 \mathrm{X}_{8}$ \\
\hline
\end{tabular}

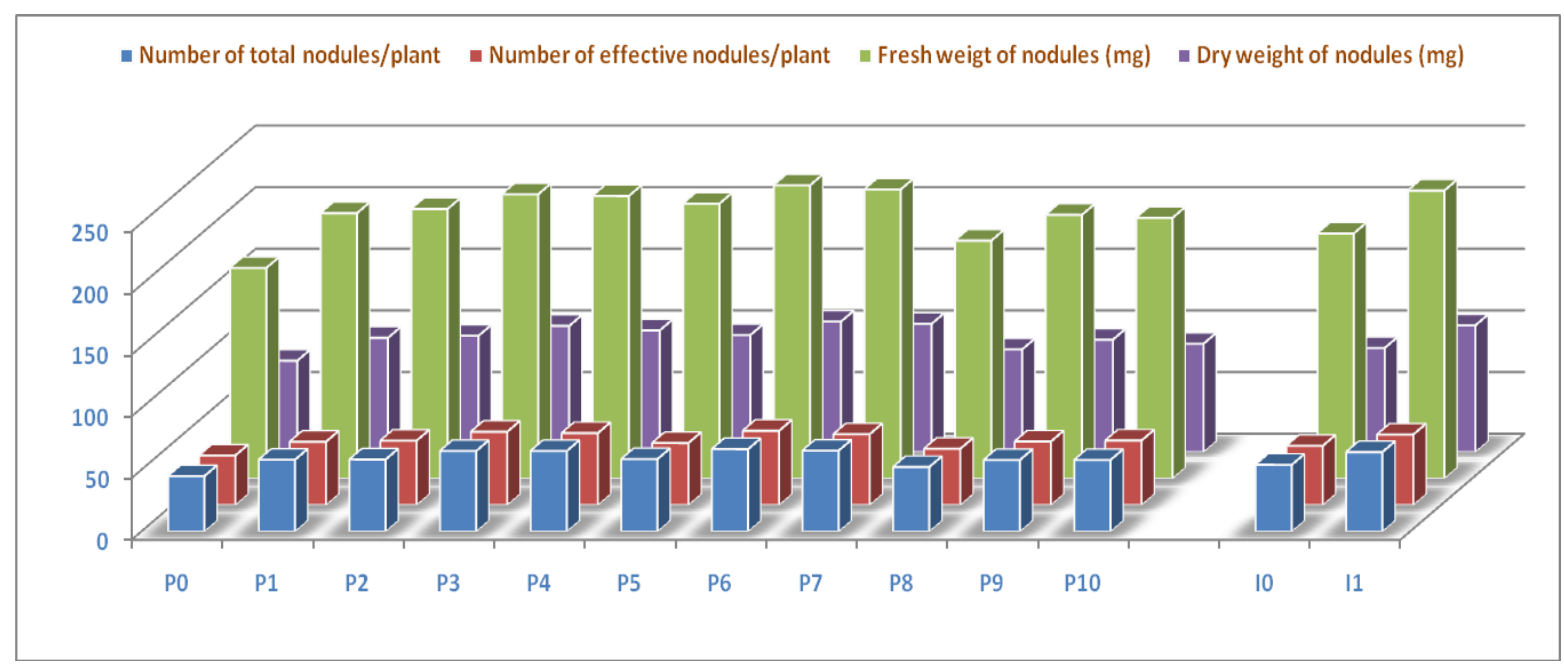

Fig.1 Effect of integrated phosphorus management on number and weight of nodules/plant in groundnut

\section{Correlation and regression studies}

Correlation coefficients and regression equations were worked out to study the relationship of pod yield with crop dry matter accumulation at harvest, total and effective nodules/plant, fresh and dry weight of nodules/plant of crop. The values calculated are presented in Table 5. The results of correlation coefficients indicated that pod yield of groundnut was significantly and positively correlated with crop dry matter accumulation at harvest $(\mathrm{r}=0.981)$, number of total nodules/plant $(\mathrm{r}=0.972)$, effective nodules/plant $(\mathrm{r}=0.986)$, fresh weight of nodules $(\mathrm{r}=0.956)$, dry weight of nodules $(\mathrm{r}$ $=0.959)$, number of pods/plant $(r=0.968)$. The regression equations (Table 5) showed that unit increase in crop dry matter at harvest, number of total nodules, effective number of nodules, fresh weight of nodules, dry weight of nodules increased the pod yield of groundnut by 6.85, 37.66, 39.21, 11.92 and $23.55 \mathrm{~kg} / \mathrm{ha}$, respectively.

\section{References}

Arnon, D.I. 1949. Copper enzymes in isolated chloroplasts polyphenol oxidase in Beta vulgaris. Plant Physiology 24: 1-5.

Choudhary, R.R. and Yadav, H.L. 2017. Effect of Conjunctive use of phosphorus and Bio-Organics on phosphorus content and uptake in summer groundnut (Arachis hypogaea L.). International Journal of Current 
Microbiology and Applied Sciences 6(8): 1618-1621.

Das, T., Debnath, P., Satpute, S.B. and Bandyopadhyay. 2015. Effect of phosphorus enriched vermicompost on growth and yield of groundnut (Arachis hypogaea L.) as influenced by soil phosphorus use efficiency. Indian Journal of Science and Technology 8(11): 0974-6846.

Dhadge, S.M. and Satpute, N.R. 2014.Effect of integrated nutrient management on growth, yield and quality of summer groundnut (Aarchis hypogaea L.). International Journal of Agricultural Sciences 10(1): 314-316.

Fisher, R.A. 1950. Statistical Methods for Research Workers. Oliver and Boyd, Edinburg, Landon.

Hasan, M. and Ismail, B.S. 2016.Effect of phosphorus fertilizers on growth and yield of groundnut. Journal of Environmental Biology 30(2): 275-281.

Murhty, R.K., Vasudev, H.S., Devagiri, G.M., Umashankar, N. and Raveendra, H.R. 2009. Effect of Integrated nutrient management of growth and yield parameters and nutrient uptake of groundnut (Arachis hypogaea L.). Mysore Journal Agricultural Science 43(4): 696-699.
Patil, S.R., Kadam, S.R., Kalegore, N.K. and Dadgale, P.R. 2014. Effect of inorganic and bio-fertilizers on growth and yield of summer groundnut. Advance Research Journal of Crop Improvement 5(1): 23-25.

Radford, P.J. 1967. Growth analysis formulae-their use and abuse. Crop Science 7: 171-175.

Sorrensen, R., Butts, C., Lamb, M. and Rowland, D. 2004. Five Years of Subsurface Drip Irrigation on Peanut. Research and Extension Bulletin No. 2004.

Taru, V.B., Khagya, I.Z., Mshelia, S.I. and Adebayo, E.F. 2008.Economic efficiency of resource use in groundnut production in Adamawa State of Nigeria. World Journal of Agricultural Science 56: 4896- 9000.

Tilak, K.V.B.R. and Annapurna, K. 1993. Effect of PSB in different crops. National Academy Science LettersIndia 59: 315-317.

Zalate, P.Y. and Padmani, D.R. 2009. Effect of organic manure and biofertilizers on growth and yield attributing characters of kharif groundnut (Arachis hypogaea L.).International Journal of Agricultural Sciences 5(2): 343-345.

\section{How to cite this article:}

Rajbala Sharma, S. S. Yadav, Jitendra Singh Bamboriya and Sarita. 2020. Effect of Integrated Phosphorus Management on Growth and Yield of Groundnut (Arachis hypogaea L.). Int.J.Curr.Microbiol.App.Sci. 9(04): 1079-1088. doi: https://doi.org/10.20546/ijcmas.2020.904.128 